\title{
Variações e recriações cinematográficas de Madame Bovary
}

\author{
Variaciones y recreaciones cinematográficas de \\ Madame Bovary
}

\section{Variations and cinematographic recreations of Madame Bovary}

\section{Luis Carlos Pimenta Gonçalves}

Docente e vice-coordenador dos cursos de Mestrado em Estudos Comparados Literatura e outras Artes e do Mestrado em Estudos Portugueses Multidisciplinares

(Universidade Aberta)

http://orcid.org/0000-0003-4183-2869

Portugal

Data de recepção: 30 de janeiro de 2019

Data de revisão: 4 de junho de 2019

Data de publicação: 1 de julho de 2019

Para citar este artigo: Pimenta Gonçalves, L. C. (2019). Variações e recriações cinematográficas de Madame Bovary, Icono 14, 17 (2), 82-108. doi: 10.7195/ri14.v17i2.1355 


\section{Resumo}

A literatura tem sido desde a criação do cinematógrafo fonte inspiradora de filmes e guiões. Obras literárias pertencentes ao cânone literário foram e são, por conseguinte, objeto apetecivel de inúmeras adaptações e não podia escapar a este fenómeno o romance que constitui um marco da literatura realista, Madame Bovary, de Gustave Flaubert. Contam-se cerca de vinte adaptações e versões do romance, nomeadamente as dos cineastas franceses Jean Renoir (1933) e Claude Chabrol (1991), e americano Vicente Minelli (1949).

Neste artigo debruçar-me-ei sobre duas variações interartísticas e inter-semióticas baseadas em adaptações indiretas do romance de Flaubert. Uma portuguesa, Vale Abraão (1993), de Manoel de Oliveira, a partir do romance homónimo de Agustina Bessa-Luís centrado na figura de uma Bovary duriense, e outra francesa, Gemma Bovery (2014), de Anne Fontaine, recriação da novela gráfica de Posy Simmonds onde um leitor do romance francês tenta ler o real através da ficção.

\section{Palavras chave}

Cinema francês; Cinema português; Adaptação cinematográfica; Literatura francesa do séc. XIX; Literatura portuguesa do séc. XX; Novela gráfica

\section{Resumen}

La literatura ha sido fuente de inspiración de películas y guiones desde la creación del cinematógrafo. Obras literarias pertenecientes al canon literario han sido y son objeto de innumerables adaptaciones y no ha podido escapar a este fenomeno la novela sobresaliente de la literatura realista, Madame Bovary, de Gustave Flaubert. Cuenta con más de veinte adaptaciones y versiones realizadas por cineastas franceses como Jean Renoir (1933) o Claude Chabrol (1991), americanos como Vicente Minelli (1949.

En este artículo analizaré dos variaciones inter-artísiticas e inter-semióticas basadas en adaptaciones indirectas de la novela de Flaubert. Una portuguesa, Vale Abraão (1993), de Manoel de Oliveira, a partir de la novela homónima de Agustina 
Bessa-Luís centrado en la figura de una Bovary del Duero; y otra francesa, Gemma Bovery (2014), de Anne Fontaine, recreación de la novela gráfica de Posy Simmonds en la que un lector de la novela francesa intenta leer la realidad a través de la ficción.

\section{Palabras clave}

Cine francés; Cine portugués; Adaptación cinematográfica; Literatura francesa siglo XIX; Literatura portuguesa siglo XX; Novela gráfica

\section{Abstract}

Since the creation of the cinematograph, literature has been a source of inspiration for films and scripts. Consequently, literature from the canon were and continue to be desirable for numerous adaptations and Madame Bovary by Gustave Flaubert, the striking realist novel, couldn't have escaped this phenomenon. There are around twenty adaptations and different versions of the novel by French film directors such as Jean Renoir (1933) and Claude Chabrol (1991), American directors such as Vicente Minelli (1949).

In this article, I am going to focus on two inter-artistic and intersemiotic variations from indirect adaptations of Flaubert. One, Portuguese, Vale Abraão (1993), by Manoel de Oliveira, based on the novel with the same name by Agustina Bessa-Luís, where Bovary is from the Douro region, and the other French, Gemma Bovery (2014), by Anne Fontaine, a recreation of the graphic novel by Posy Simmonds where a reader of a French novel attempts to read the real through fiction.

\section{Key Words}

French cinema; Portuguese cinema; Cinematographic adaptations; 19th century french literature; 20th century portuguese literature; Graphic novel 


\section{Introdução}

Desde os seus primórdios, o cinema tem ido buscar inspiração, mas também reconhecimento social e cultural à literatura. Georges Méliès filma em 1902 uma paródica Viagem à Lua que pouco se aparenta, salvo o título, com o romance epónimo de Jules Verne. A obra de Alexandre Dumas, Os Três Mosqueteiros, é adaptada pela primeira vez, em 1912, por André Calmettes e André Pouctal; Max Linder dez anos mais tarde parodia a obra no próprio título através de um calembur, L'Étroit Mousquetaire (literalmente "0 estreito mosqueteiro"). Ainda na época do cinema mudo é bastante revelador deste movimento a criação pela produtora de filmes Pathé, em 1908, do Film d'Art. Inicialmente trata-se de transpor para o cinema episódios históricos, mas rapidamente serão adaptadas obras literárias. No mesmo ano, os irmãos Pathé estão igualmente na origem da Société Cinématographique des Auteurs et Gens de Lettres, empresa que tem por finalidade a adaptação de obras populares da literatura. Assim, Albert Capellani adapta L'Assommoir, em 1908, Germinal, em 1913, romances de Zola, assim como Les Misérables em quatro episódios, em 1912-1913.

Deste modo, obras pertencentes ao cânone literário tornam-se objeto apetecível de inúmeras adaptações e não podia escapar a este fenómeno o romance marcante da literatura realista em França, Madame Bovary, de Gustave Flaubert. Contam-se cerca de vinte adaptações e versões do romance realizadas por cineastas franceses como Jean Renoir (1933) ou Claude Chabrol (1991), americanos como Vicente Minelli (1949) e mais recentemente uma surpreendente variação provocatoriamente intitulada I am not Madame Bovary (2016), do chinês Feng Xiaogang. A reutilização da mesma obra literária como fonte de inspiração deve-se tanto à sua importância na história da literatura como ao facto de ter uma heroína que se tornou um arquétipo, para não dizer uma figura mítica que escapa ao seu criador e se reinventa em prequelas e sequelas, em adaptações para banda desenhada e cinema.

Madame Bovary com o seu subtítulo, quase sempre esquecido, de Costumes da Província (Moeurs de province) foi inicialmente publicado em folhetim quinzenal na Revue de Paris no último trimestre de 1856 e posteriormente em livro, em 1857, depois de um processo onde o autor foi acusado de ofensas à moral pública e à 
religião de que seria absolvido após um julgamento que durou dez dias. 0 processo contribuiu em grande medida para o sucesso imediato da obra junto dos leitores. A posteridade da obra não é, contudo, unicamente devedora deste aspeto circunstancial. Não é tanto a intriga, a história de uma jovem duma pequena vila da Normandia da primeira metade do século XIX, grande leitora de obras românticas que condicionam a sua perceção da realidade, entediada no casamento com um oficial de saúde medíocre (Charles Bovary), tendo no decorrer da diegese dois amantes (Léon Dupuis e Rodolphe Boulanger) e acabando por se suicidar não por amor, mas por excesso de dívidas (desfecho que concede uma tonalidade temática bem mais moderna a este romance oitocentista) mas a força do estilo com o recurso ao discurso indireto livre que permite uma neutralidade narrativa e a ironia constante de um narrador omnisciente que dão ao romance de Flaubert o seu lugar cimeiro na literatura francesa e mundial. 0 próprio título da obra (conservado em francês nas traduções portuguesas) Madame Bovary, indica a sobredeterminação social e cultural da mulher do seculo XIX que não existe sequer na individualidade do seu nome próprio, mas unicamente através do apelido do marido. ${ }^{1}$ É bastante sintomático que a novela gráfica de Posy Simmonds, Gemma Bovery, variação paródica dos finais do século XX do modelo flaubertiano de que falaremos neste artigo, tenha por título o nome próprio da protagonista, apesar de que associado ao apelido do marido para conservar um elo de ligação com o hipotexto.

\section{Material e Métodos}

Neste artigo debruçar-nos-emos sobre duas variações interartísticas baseadas em adaptações indiretas do romance de Flaubert: uma portuguesa, Vale Abraão (1993), de Manoel de Oliveira, a partir do romance homónimo de Agustina BessaLuís centrado na figura de uma Bovary duriense no século XX, e outra francesa, Gemma Bovery (2014), de Anne Fontaine, recriação da novela gráfica de Posy Simmonds onde uma personagem de finais do século XX, Joubert, leitor compulsivo da obra do escritor francês, tenta ler o real através da ficção. Utilizaremos igualmente artigos e entrevista publicados, assim como mesas redondas filmadas disponiveis na internet. 
Compararemos as várias obras e observaremos similitudes e diferenças, utilizando ferramentas metodológicas e conceitos provenientes da literatura comparada, da narratologia, dos estudos inter-artes e da análise fílmica. Apresentaremos alguns exemplos mais notáveis dos diálogos intertextuais que estabelecem com as obras que lhes deram origem.

\section{Resultados}

Podemo-nos interrogar sobre o que teria pensado Flaubert sobre transposições da sua obra quando só autorizou uma adaptação para libreto de Salammbô. Recusou, desta mesma obra, ilustrações como refere na sua correspondência: «Nunca enquanto for vivo serei ilustrado, pelo facto da mais bela descrição literária ser devorada pelo pior dos desenhos». Acrescentando na mesma carta:

Uma mulher desenhada parece-se com uma mulher, e pronto. A ideia está já fechada, completa, e todas as frases são inúteis, enquanto uma mulher escrita faz sonhar com mil mulheres. Consequentemente, sendo isto uma questão estética, recuso formalmente qualquer espécie de ilustração. ${ }^{2}$

As atualizações do romance oitocentista pela escritora portuguesa e pela cartoonista inglesa testemunham ainda a extrema plasticidade do texto original, das personagens e, em particular de Emma Bovary, que deu nome a uma patologia identificada por Jules de Gaultier de Laguionie (1858-1942) o "bovarismo" A obra francesa contribuiu ainda a popularizar uma frase muito provavelmente apócrifa atribuída a Flaubert: «Madame Bovary sou eu», glosada por escritores e críticos quando se trata de relevar traços biográficos na ficção ou da indissociabilidade entre criador e criatura. ${ }^{4}$

As transposições recriando o universo imagético de um escritor devem guardar uma relação reconhecível com o modelo e em simultâneo distanciar-se dele autonomizando-se. 0s dois filmes retomam os títulos das recriações que adaptam, porém, se ainda é possível reconhecer na novela gráfica uma quase identidade com a obra francesa, Gemma Bovery e Madame Bovary, tal não se afigura possivel no romance português, Vale Abraão, cujo hipotexto só será revelado no decorrer 
da leitura. Manoel de Oliveira justifica o título em dois momentos distintos do genérico. Em primeiro lugar, a seguir ao nome do produtor Paulo Branco, escrito a branco num ecrã preto, uma voz-off que diz um texto proveniente do fim da primeira metade do romance, explica parcialmente o título enquanto é projetada uma imagem aparentemente fixa do vale do Douro que não é uma fotografia ou fotograma por se notar uma ligeira vibração que suspende o tempo do filme para dar lugar ao tempo da narração do romance.

0 patriarca Abraão tinha um costume arcaico: o de usar a beleza da mulher, Sara, como solução das suas dificuldades. Para isso intitulava-a sua irmã, o que lhe deixava caminho para o desejo dos outros homens. (Bessa-Luís, 1991, p. $49-50)^{5}$

Em segundo lugar, depois do genérico que ocorre durante um longo travelling do rio Douro filmado de um comboio, surge uma informação complementar sobre a etimologia do topónimo. Esta precisão provém das duas primeiras páginas do romance, aí se descobre que um certo Abraão de Paiva, «físico engenhoso», após um parto malsucedido se refugia num vale que terá doravante por nome Vale Abraão.

\subsection{Vale Abraão, as recriações portuguesas de Madame Bovary}

Inicialmente, Manoel de Oliveira pretendeu realizar uma versão de Madame Bovary, em França, com atores franceses, mas soube então que Claude Chabrol estava a adaptar o romance. Assim, ocorreu-lhe a ideia, bem mais original, de rodar no norte de Portugal uma reinterpretação contemporânea, desafiando para tal a escritora Agustina Bessa-Luís de quem já adaptara Fanny Owen.

Anos mais tarde conta a relação complexa entre o realizador e a criatura intermediada pelos olhares de dois romancistas.

Apreendi o espírito de Madame Bovary e propu-lo a Agustina Bessa-Luís. Em Madame Bovary, é um homem que escreve sobre uma mulher. Isso originou o Bovarysmo que é retomado depois por Agustina, uma mulher que fala de 
mulheres. E eu, quando retomo Agustina, sou um homem que fala de mulheres através da visão de uma mulher, segundo o ponto de vista de Flaubert. (Baecque \& Parsi, 1999, p. 71-72)

Numa conferência no Institut Franco-Portugais, em 28 de novembro de 1990, Agustina Bessa-Luís afirmou que nos dias de hoje a personagem de Flaubert seria um anacronismo. Contrariamente ao que adianta à revista Ler, do último trimestre de 1990, de não querer incluir explicitamente referências à obra do mestre francês ao decidir escrever sobre uma Bovary duriense são constantes as alusões a Madame Bovary no seu livro. Para escrever Vale Abraão precisou de melhor entender a personagem criada por Flaubert. Assim o assevera numa entrevista ao jornal Público, em 15/10/1993, aquando da saída do filme.

Importante foi a Bovary: tive que pensar o que seria uma Bovary naquela região, que nada tem a ver com a Bovary de Flaubert nem com a de Renoir, que é excelente porque descreve com fidelidade extraordinária o livro...

Existem inúmeras similitudes entre o romance de Flaubert e o de Bessa-Luís, ao qual nem sempre se manterá fiel Manoel de Oliveira como se o realizador tentasse reencontrar em certos momentos o hipotexto flaubertiano no hipertexto da escritora portuguesa, resgatando a memória que tem do romance francês. A Ema de Oliveira é assim mais provinciana que a de Agustina que afirma o seu cosmopolitismo através de viagens pelo mundo fora. Às viagens de Emma Bovary de Flaubert na diligência L'Hirondelle, entre a pequena vila onde reside, Yonville, e a capital provinciana Ruão correspondem no filme as deslocações ziguezagueantes de carro ou de barco pelas encostas e nos meandros do rio Douro e as referências a idas ao Porto.

A personagem central das várias obras chama-se Ema (Emma no texto francês) casa-se, mais para escapar ao tédio que por amor com um médico viúvo, Carlos, Charles que não consegue entender as inquietações e ambições da jovem esposa. Só ao fim de três anos as heroínas francesa e portuguesa ficam grávidas e ocupam-se pouco das filhas, têm vários amantes (dois no caso de Emma Bovary e três no caso de Ema Paiva), um deles proprietário de uma quinta apalaçada 
(La Huchette num caso, 0 Vesúvio noutro). Sonham com uma vida que não conseguem alcançar quando se vêem confrontadas com uma classe social mais alta (aristocrática ou burguesa) no baile de la Vaubeyssard ou no das Jacas ${ }^{6}$ onde Ema Paiva fica consternada com a falta de elegância do marido.

E, no entanto, o baile fez nela uma impressão fulminante. Mediu, de repente, a sua situação de jovem esposa de um homem medíocre, cujas peúgas escorregavam para os tornozelos e que usava sapatões de marcha com o smoking mal talhado. (Bessa-Luís, 1991, p. 49-50)

As duas heroínas portuguesas, depois do episódio do baile, conservam uma tabaqueira esquecida ou perdida por quem as fez dançar e que irá funcionar como uma forma sensual de reavivar a memória de um momento excecional, de rutura com uma vida medíocre. Julgando-se diferentes do que são na realidade e querendo ter um estilo de vida incompatível com os rendimentos dos maridos, endividam-se.

Quis pratos de prata para marcar os lugares, e Carlos teve que desdobrar a sua cirurgia para pagar em prestações essa extravagância. (Bessa-Luís, 1991, p. 59)

Qualquer peça de vestuário importava num preço exorbitante; era roupa de teatro, destinada a condizer com a fábula, e não adequada à realidade. Devia já muito dinheiro nas lojas mais caras [...]. (Bessa-Luís, 1991, p. 206)

No final, as duas personagens acabam por morrer tragicamente, suicidando-se no romance francês, acidentalmente ou não no romance português, atendendo à afirmação de Carlos: «Não sei se foi desastre, se foi outra coisa» (Bessa-Luís, 1991, p. 206). 0 filme mostra o momento da morte, Ema pisa a tábua podre de um pontão e cai à água sem que se consiga verdadeiramente saber se foi intencional ou não, vistas as várias advertências que surgem no filme sobre o estado deplorável do acesso aos barcos. 0 ritual de preparação da personagem antes de sair de casa, o longo travelling acompanhando-a através do laranjal e finalmente o pisar das pranchas podres, tudo parece indiciar que ouve premeditação na queda fatal ao rio. 


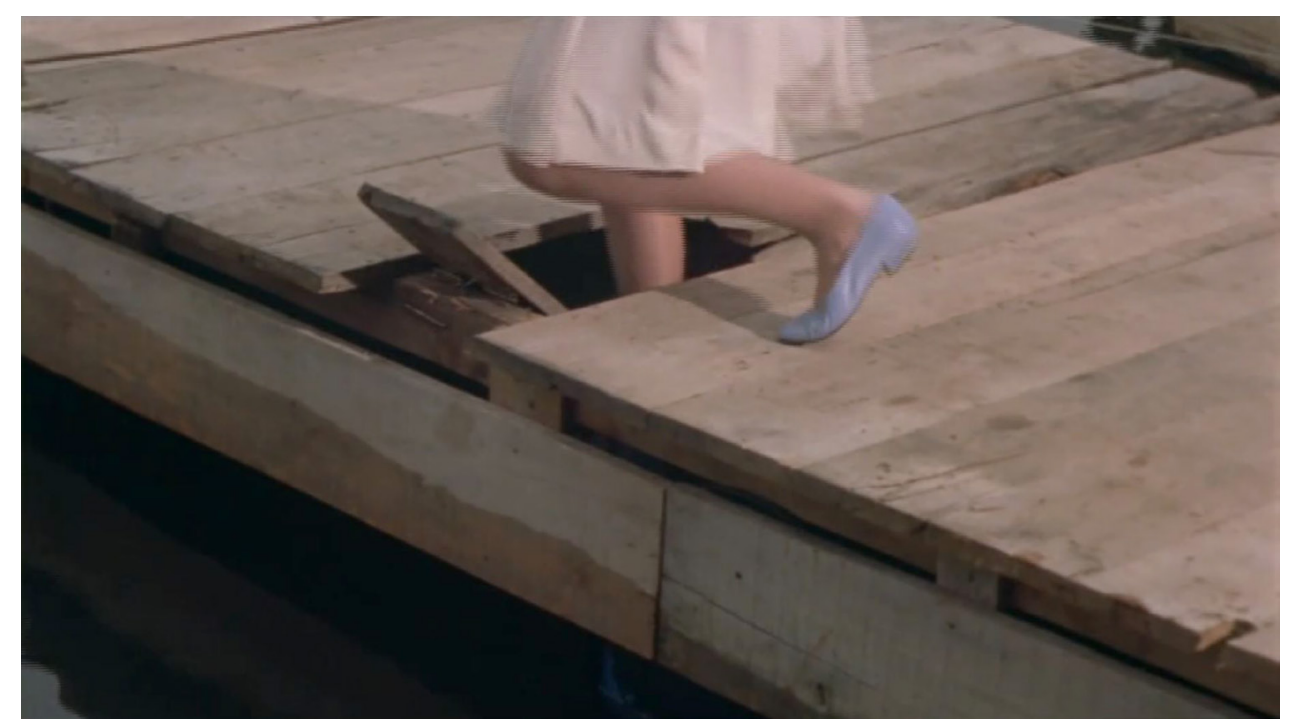

Ilustração 1: Oliveira - Vale Abraão

Charles e Carlos sobreviverão pouco tempo à morte da mulher e serão encontrados mortos no exterior da casa.

No romance português e no filme, Ema Paiva é comparada a Emma Bovary por outra personagem, Pedro Lumiares, erudito e grande leitor: «Foi ele que lhe chamou a Bovarinha, com o desprendimento senhorial de quem põe nome a um cão. E, ouvindo-o, rapidamente Maria Semblano divulgou a alcunha» (Bessa-Luís, 1991, p. 77). 0 facto de utilizar um diminutivo familiar reforça a ideia que se trata de uma pálida imitação, uma redução do modelo original. Esta denominação serve inclusive de título ao capítulo IV, sublinhando ironicamente o parentesco com a personagem original. É facto que Agustina Bessa-Luís partilha com Flaubert a subtil e por vezes cruel ironia, nomeadamente na descrição da monotonia da vida provinciana, terreno fértil para o bovarismo, com a repetição dos mesmos momentos festivos.

Bovarinha que era, Ema queria sobreviver acima dessa fauna, de patos, galinhas, perus, e papagaios, que circulava pela casa em horas pré-estabelecidas, rigorosamente iguais: Natal, Ano Novo, dia de anos, festa de comunhão, de Ascensão, de Reis [...]. (Bessa-Luís, 1991, p.107-108) 
Ema Paiva afasta-se do modelo flaubertiano ao possuir um grau de liberdade e, sobretudo, uma capacidade de utilizar o humor e a ironia que faz dela, neste sentido, mais um alter ego da sua criadora: «Ela sabia fazer rir os homens, e nisso não era uma Bovary bem copiada. Ema Bovary não tinha qualquer sentido de humor, e daí a sua impaciência estéril.» (Bessa-Luís, 1991, p.246). Mais, enquanto Emma Bovary é condicionada ainda muito jovem, no convento, pela leitura de livros de amor e já adulta pela leitura de obras de autores românticos, Ema Paiva considera que o marido é dominado pelo «seu romantismo balofo que encobria a saudade do grande século, o século dezanove» (Bessa-Luís, 1991, p.268) e critica-o por ler Camilo Castelo Branco - suprema ironia da autora quando se conhece os seus gostos literários - e livros de terror. Assim, contrariamente a Emma Bovary que é uma leitora de livros sentimentais, Ema Paiva é uma leitora pouca assídua, contentando-se com as confidências e historietas das criadas da casa. Mais tarde é descrita como «preguiçosa» que «lia muito e nunca acabava um livro» (Bessa-Luís, 1991, p.196), preferindo o divertimento que encontra nos jogos televisivos. Enquanto que Emma se inspira nos romances de Eugène Sue para a decoração da casa, é no cinema, e em particular no filme de Jack Clayton, 0 Grande Gatsby (1974), que Ema Paiva se inspira para decorar a sala de talha dourada e seda pérola. A personagem criada pela escritora portuguesa não deixa, contudo, de ler algumas obras como o célebre romance de Alexandre Dumas: «Ema fora uma leitora absorta da Dama das Camélias» (Bessa-Luís, 1991, p.225) cuja personagem, Marguerite Gautier, funciona sarcasticamente de «fada madrinha». Mas a leitura mais decisiva em Vale Abraão é a do próprio romance de Flaubert motivada pelo facto de Pedro Lumiares comparar Ema Paiva a Emma Bovary.

Ema passou a ser pasto de maledicência e ainda não tinha feito nada de condenável. Foi nessa altura que lhe inventaram o título de madame Bovary.

- A Bovarinha - disse Lumiares, divertido. (Bessa-Luís, 1991, p.65)

A heroína de Vale Abraão desperta para a existência de uma obra que desconhecia e, inicialmente, vai simplesmente tentar saciar a curiosidade ao encontrar similitudes entre ela e a personagem do autor francês e sobretudo diferenças. Contudo, não encontra semelhanças apesar da releitura que faz do romance: «Nun- 
ca percebi porque me chamam a Bovarinha e já li o livro duas vezes.» (Bessa-Luís, 1991, p.209). Porém, mais por derisão que verdadeira identificação, e em jeito de desafio assume por vezes a alcunha.

- Quem fala?

- A Bovarinha.

Era a primeira vez que ela fazia uso do título que sabia darem-lhe e que primeiro, a exasperava. (Bessa-Luís, 1991, p.99)

A partir deste momento, é frequente observar-se a inscrição no texto do nome próprio e do cognome como se este fosse um atributo indissociável: «Ema, a Bovarinha» (Bessa-Luís, 1991, p.156). Mais, adiante no romance, Ema Paiva assume o apelido do modelo com orgulho: «Merecia a alcunha de madame Bovary? Pedro Lumiares ficou muito surpreendido quando ela o reivindica como uma espécie de autoelogio. [...] - A Bovary, tu? - disse Pedro Lumiares. [...] Mas uma Bovary, como?» (Bessa-Luís, 1991, p.127-128). No filme, num plano quase no início, Ema ainda adolescente tem nas mãos Madame Bovary numa edição da Lello do princípio do século $\mathrm{XX}$, mas só mais tarde surge, tal como no romance português, uma referência ao texto francês e à sua heroína.

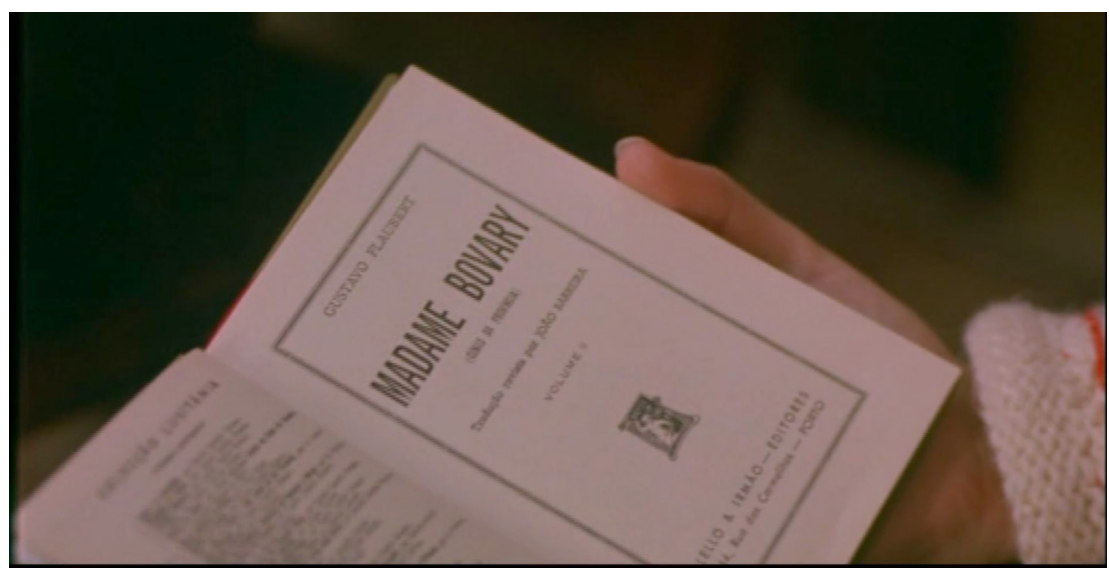

Ilustração 2: Oliveira - Vale Abraão 
Na afirmação face ao modelo comportamental e literário, Manoel de Oliveira ultrapasse o próprio romance de Agustina ao introduzir a fala: «Embora me chamem a Bovarinha, eu não sou Bovary, e muito menos Flaubert» e talvez também não Bessa-Luis - o que, a acontecer, levaria à total autonomização da criatura face aos dois autores. 0 cineasta demarca-se igualmente de Flaubert para ter maior liberdade no diálogo interartístico que estabelece com os dois romances.

0 registo explícito à obra que serve de hipotexto ao romance português também se encontra na novela gráfica como veremos de seguida.

\subsection{Gemma Bovery, variações inter-semióticas em diálogo}

Posy Simmonds, nascida em 1945, membro da Royal Society of Literature, tem uma obra de livros infantojuvenis e mantém uma colaboração regular no jornal britânico The Guardian. Caricatura a sociedade inglesa, os seus intelectuais e artistas ao retratar uma família inglesa, os Weber family. Em finais da década de 90 , entre 1997 e 1999, Simmonds desenha a novela gráfica Gemma Bovery em cem episódios para o Guardian, livremente inspirada no romance de Flaubert. Ao fazê-lo institui um diálogo com o romance de um autor que admira desde jovem ao ter descoberto o livro aos quinze anos na língua original graças a uma professora de francês, ${ }^{7}$ declarando em entrevistas tratar-se de um dos seus autores favoritos. 0 formato da novela é imposto pelo jornal à desenhadora: retangular na vertical ocupando três colunas, muito diferente das tiras que Simmonds desenhava na horizontal para os jornais.

No jornal Le Monde, de 30/01/2009, a desenhadora declara trabalhar como um realizador de cinema que começa por escolher o casting, os locais da ação e faz croquis dos sítios visitados. ${ }^{8}$ Desenha as personagens, os pormenores como a marca dos carros, o tamanho do calçado ou a cor da escova de dentes. ${ }^{9}$ 0s primeiros desenhos representam uma Gemma Bovery que nem é "muito bela", segundo as palavras da sua criadora. No início, por se tratar da recriação de um romance do século XIX, Gemma é representada com um olhar lânguido consentâneo com a imagem que a desenhadora tinha da mulher oitocentista. Na conceção da personagem, visível nalgumas edições que reproduzem os desenhos preliminares do «sketchbook», 
inspira-se em figuras existentes anónimas ou célebres, nomeadamente na princesa Diana que acabara de sofrer o acidente mortal à época dos primeiros episódios. Simmonds explica que se o faz é pela proximidade com a personagem de Flaubert ao sofrer desgostos sentimentais e ao ter um fim trágico. Porém, da princesa de Gales só conservará a forma dos olhos e a inquietude do olhar.

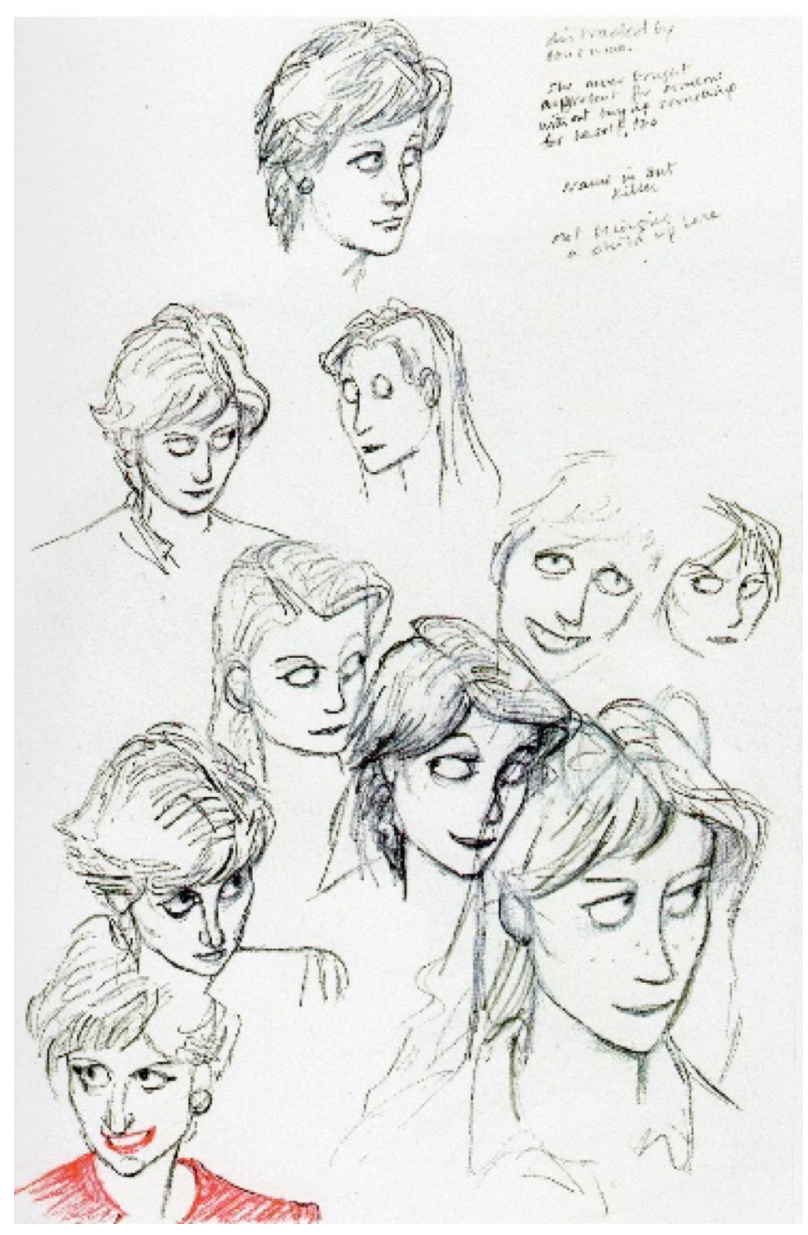

Ilustração 3: «Sketchbook» in Posy Simmonds, 2014 
Quanto ao protagonista, o narrador da história, o padeiro Joubert, parece-se com um homem que viu num bar em França com aspeto de um antigo "soixantehuitard". Depois deste trabalho preliminar, as personagens tornam-se tão reais que a desenhadora diz ouvir as suas vozes. ${ }^{10}$

A intriga publicada em folhetim evoluiu com o passar do tempo. Por exemplo, o episódio da morte da heroína era necessário para conservar o desfecho trágico do romance, mas a desenhadora não sabia ainda como. Quando a conclusão da novela em folhetim se aproximou, Posy Simmonds que imaginara inicialmente que Gemma morreria por overdose de medicamentos, ao desenhá-lo sentiu uma resistência da própria personagem que não queria morrer dessa forma.

Não é de estranhar que a realizadora Anne Fontaine que tem retratado nos seus filmes personagens de mulheres (Les histoires d'amour finissent mal... en général, 1992; Nathalie, 2003; Coco avant Chanel, 2009; Perfect Mothers, 2013; Les Innocentes, 2016) tenha sido atraída por este universo tanto mais, como sublinha o editor francês e cotradutor Jean-Luc Fromental, ${ }^{11}$ que os próprios desenhos revelam, surpreendentemente, o que designa pela expressão inglesa "acting", o trabalho do ator. A própria desenhadora utiliza o termo "mise en scène" (encenação em português) para referir a colocação das imagens e a marcação das personagens. Da mesma forma que Posy Simmonds traduz para a linguagem visual da banda desenhada, atualiza para o século XX e naturaliza para uma realidade intercultu$\mathrm{ral}^{12}$ com o duplo olhar dos franceses sobre os ingleses e dos ingleses sobre os franceses, a realizadora Anne Fontaine ao adaptar a novela gráfica procede ao mesmo exercício num filme estreado uma quinzena de anos depois da BD publicada em livro.

Se Simmonds assumiu claramente uma rutura com o modelo original de Flaubert, tal já não se afigura necessário no filme de Fontaine em relação à novela gráfica. Porém, ao realizar um filme em francês destinado em primeiro lugar a espetadores franceses e francófonos, a cineasta acaba por "afrancesar" a novela e acentuar as alusões interartísticas à obra de Flaubert e à realidade francesa. Anne Fontaine explica durante uma apresentação do filme no, Centro Pompidou de Paris, que descobriu a novela gráfica no escritório do seu produtor de filmes e ficou ime- 
diatamente intrigada com os desenhos e o título aludindo ao romance de Flaubert que descobrira aos dezasseis anos. Apreciou o humor da novela gráfica que, segundo ela, está ausente do romance. Sentiu de imediato empatia pelo tom empregue em Gemma Bovery e decidiu posteriormente adaptá-la. Antes releu a obra do autor francês, mas de forma não linear, talvez para não se deixar subjugar excessivamente pela escrita do autor e pela intriga, interessando-se por alguns episódios. $\mathrm{Na}$ preparação do filme conversou em Londres com Posy Simmonds e descobriu a extrema precisão e rigor do método de trabalho da desenhadora. Ficou "intimidada" perante a tarefa da adaptação por ser necessário "atraiçoar sem, ao mesmo tempo, atraiçoar". Com o argumentista Pascal Bonitzer acabou por pedir conselho a Posy Simmonds que colaborou inicialmente nas cenas em inglês e depois nas cenas em francês. No argumento do filme estavam previstas sequências na Inglaterra entre Gemma e Patrick, o seu primeiro amante, que foram em parte filmadas, mas que acabaram por desaparecer do filme por receio de quebra do ritmo. A versão cinematográfica de Gemma Bovary recorre menos a flashbacks que a novela gráfica a analepses narrativas.

No dossier de imprensa do filme declarou que o trabalho dela era prolongar a BD. ${ }^{13}$ Existem, assim, cenas que se assumem como sendo fiéis ao livro e outras que não constam sequer da novela. A relação entre as personagens é mais sensual no filme, sobretudo quando se trata do olhar de Joubert sobre Gemma num processo de focalização interna onde a câmara se detém sobre o corpo da heroína. ${ }^{14}$

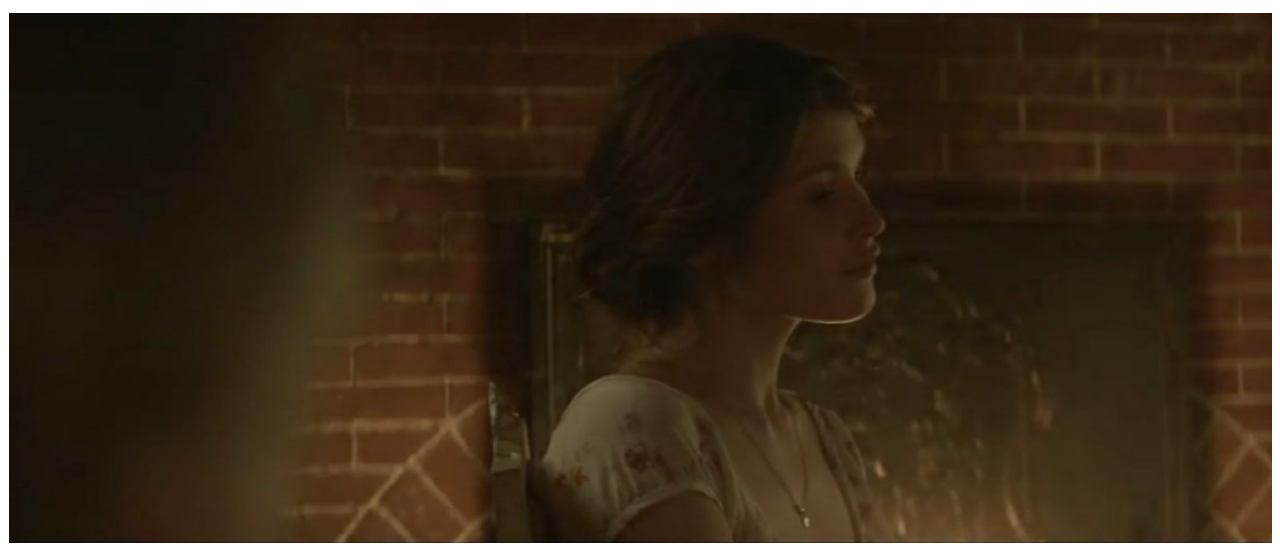



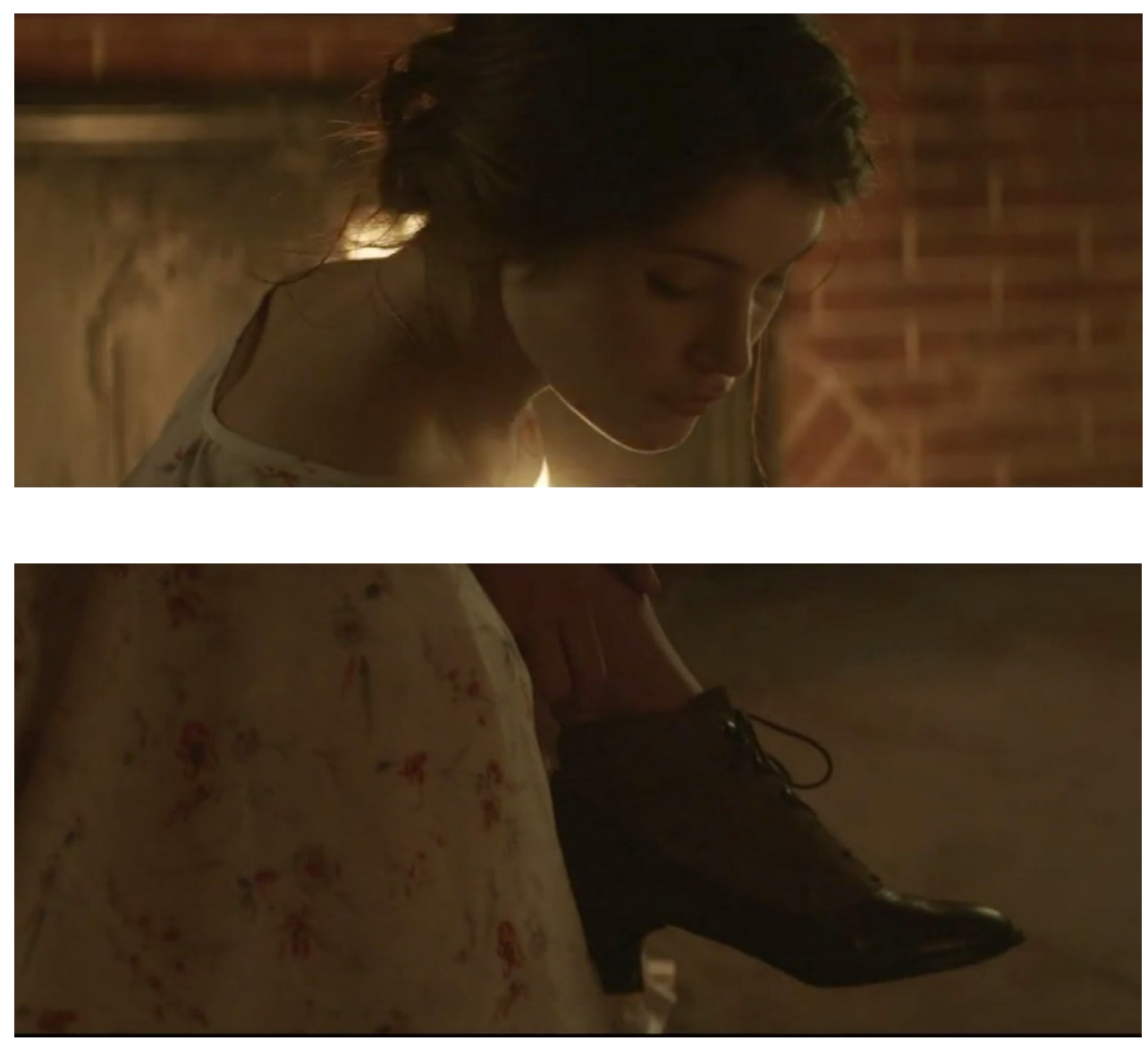

Ilustrações 4,5 e 6: Anne Fontaine - Gemma Bovery

Além disso, Anne Fontaine considera que o final encontrado por Posy Simmonds não funcionaria num filme que tenta, apesar do desfecho, encontrar o tom leve da comédia. 0 "epílogo" da novela conta o que aconteceu às principais personagens depois da morte, a ida ritual ao cemitério, a chegada de novos vizinhos e o nome auspicioso da mulher, Jane Eyre. Fontaine preferiu dar maior ênfase à instalação e a uma brincadeira do filho de Joubert que convence o pai que os novos vizinhos são russos e que ela se chama Ana Kalénine, alusão transparente ao romance de Tolstoi, Anna Karenina, cuja temática é próxima de Madame Bovary. Equivocado, o padeiro dá as boas-vindas à nova vizinha que julga ser russa num hilariante quiproquó. Este final alternativo foi inclusive validado pela cartoonista. 
Tal como se apresenta, a novela na sua relação entre texto e imagem está muito próxima de um storyboard cinematográfico, o que podia ter facilitado o trabalho de adaptação. Talvez devido a esta peculiaridade, Anne Fontaine teve de se libertar da novela, tal como o fez Simmonds relativamente ao romance de Flaubert. A maior dificuldade foi a criação da personagem de Joubert que na novela age como um escritor verboso, fala muito e, no filme, era necessário dar-lhe uma corporalidade. A cineasta pensou de imediato no ator Fabrice Luchini para o interpretar por ser «intrinsecamente francês» e ter «Flaubert nas veias». ${ }^{15}$ Na passagem da novela para o filme verifica-se a alteração da nacionalidade de uma personagem secundária, a senhora Rankin que em vez de inglesa é uma francesa casada com um inglês. Esta franco-inglesa no filme é ainda mais caricatural que no original com os seus preconceitos culturais característicos da burguesia endinheirada inglesa que reside intermitentemente em França. Enquanto que no livro a personagem se exprima dando alguns erros comuns aos locutores ingleses falando francês, a personagem interpretada pela atriz Elsa Zylberstein passa de uma língua para a outra sem aparente dificuldade, não tanto para se fazer entender do seu interlocutor, mas mais como marca distintiva de algum snobismo. A tonalidade do carácter de Gemma Bovary é também diferente nas duas obras, na novela aparente-se mais com o modelo francês que tem algo de brutal, por vezes cruel, para não dizer «pouco simpática», nas palavras de Simmonds, enquanto no filme a personagem é unicamente uma insatisfeita em relação aos seres, ao destino e que tenta reencontrar-se. A visão que Joubert tem de Gemma é da ordem do fantasma onde a literatura surge como mais poderosa e fascinante que o real. 0 que não corresponde de todo à perceção que tem Gemma da literatura. De forma muito imagética Anne Fontaine descreve a heroína de Flaubert e implicitamente do bovarismo como sendo «alguém que está debaixo de uma macieira à espera de peras», característica que se pode aplicar também à personagem da novela e do filme. Joubert ao projetar a ficção na realidade, ao querer interpretar a vida à luz de um romance, considera a obra de Flaubert como um conjunto de vaticínios que se irão realizar. Por temer e ao mesmo tempo desejar o poder da literatura sobre a vida, o padeiro interfere no destino de Gemma, agindo como um alter-ego do escritor ${ }^{16}$ e da própria cartoonista que manipula as suas criaturas. É, no verdadeiro sentido da palavra, um marionetista como reforça o texto em inglês quando Joubert prevê o encontro de Gemma Bovery e do jovem estudante em Direito, Hervé de Bressigny. ${ }^{17}$ 
It was then that I noticed Herve de Bressigny also standing there like a dummy.

Something very strange happened. The second after my eyes rested upon him it was as if, like a film director, I had shouted "ACTION!" He came to life. He spoke to Gemma! It was as if I had willed him to do it, and as if I had directed Gemma to... (Simmonds, 2001, p.45). ${ }^{18}$

Joubert age igualmente como cineasta ao proferir mentalmente a palavra performativa "AÇÃO". Inclusive, Simmonds ficou particularmente emocionada ao descobrir que desenhos e pensamentos deste episódio ganhavam vida no filme.

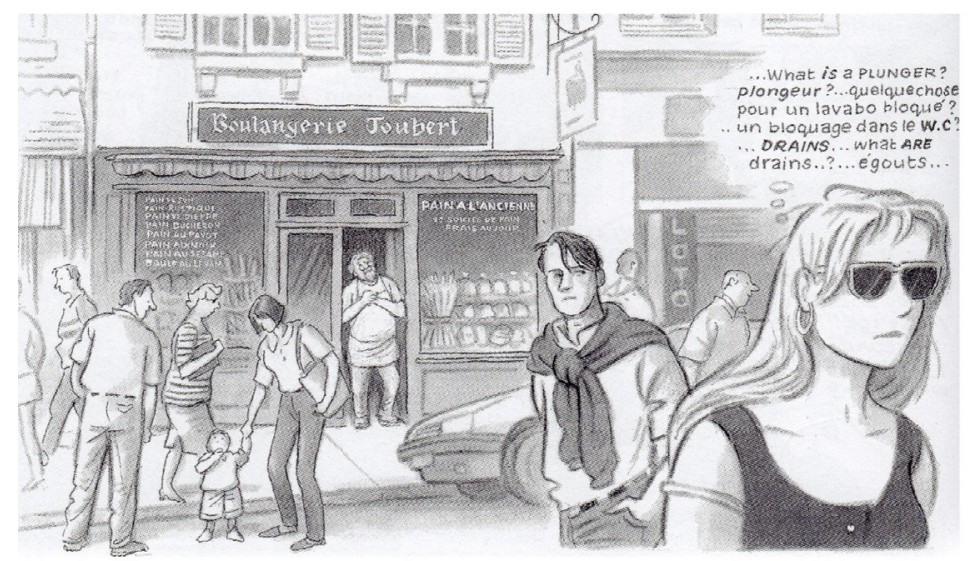

Ilustração 7: Simmonds, 2001, p.44

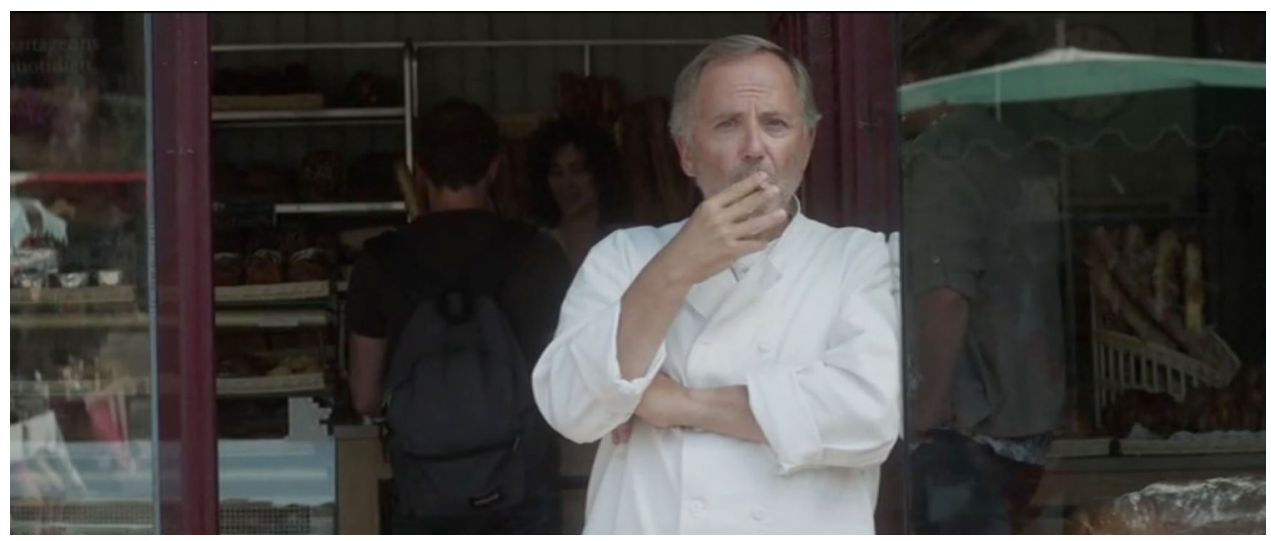

Ilustração 8: Fabrice Luchini interpreta Martin Joubert 
Joubert enquanto manipulador de fantoches não é muito diferente, neste aspeto, de Pedro Lumiares quando a narradora refere a relação que este tem com Ema Paiva: «Ela a sua boneca, que estripava e armava outra vez, sabendo tudo sobre as suas molas e engonços» (Bessa-Luís, 1991, p.235).

Quando começou a redigir o texto da novela gráfica, Simmonds utilizou a terceira pessoa do singular e ao ler em voz alta, tal como o fez Flaubert ao redigir o romance, pronunciou algumas palavras como faria um francês falando em inglês. ${ }^{19}$ É durante esta fase da leitura em voz alta que sente a necessidade de pôr na primeira pessoa os pensamentos de Joubert que se torna o narrador/testemunha da vida de Gemma. A outra voz que assume o "eu" é a própria Gemma através do seu diário que será roubado por Joubert e lido por este depois da morte da protagonista numa analepse narrativa que encontramos também no filme sob forma de flashback. Esta voz diarista está menos presente no filme para evitar longas sequências em off. A outra voz é a da própria Simmonds que está, como ela explica, do outro lado da «câmara» observando tudo, que vive «através dos outros» e «por procuração», como também refere Fontaine. A cineasta insere uma outra voz durante o genérico ao colocar um excerto de uma emissão radiofónica em francês ${ }^{20}$ onde é lido um trecho do baile de la Vaubeysard ${ }^{21}$, episódio essencial do romance de Flaubert ao som anacrónico de 0 Belo Danúbio Azul de Richard Stauss, música composta em 1867, dez anos depois do romance. ${ }^{22}$ Esta valsa será também utilizada durante o episódio do baile pelo cineasta Jacques Chabrol, na sua Madame Bovary (1991) interpretada por Isabelle Huppert. É notável que a realizadora recrie e condense o excerto da emissão radiofónica que aparece referida na ficha técnica final. Apesar de reproduzir a gravação de uma curta intervenção do apresentador Raphaël Enthoven e de um entrevistado, Patrick Dandrey, o excerto encontra-se resumido como se pode facilmente comprovar ao ouvir a emissão disponível no site da emissora. Esta transformação revela que mesmo ao integrar um documento que parece ser autêntico, a realizadora recria-o e ficcionaliza-o sem, contudo, deturpar, o seu sentido geral. Ao destacar as personagens e o seu caráter simbólico ao mesmo tempo que se vê a farinha a ser vertida, a mistura dos vários ingredientes, o pão a ser finalmente amassado e cozido, é metaforicamente indicado que um filme é uma combinatória de elementos (planos-sequência, imagens, música, palavras, inserção de fontes audiovisuais) de onde sobressaiam as personagens e, evidentemente, a primeira personagem que surge no filme: Joubert. Para um espectador 
que conhece a tonalidade peculiar da emissora pública France Culture é reforçada a ideia que o filme se inscreve na dimensão mais artística e cultural da $7^{\mathrm{a}}$ arte.

«Alors on est à la Vaubeysard, le fameux bal de la Vaubeysard, épisode cardinal de l'existence de Madame Bovary, c'est-à-dire peut-être le moment où ses rêves, du moins le croit-elle, s'incarnent.

Patrick Dandrey - Bien sûr !

- Et qui, à cet égard, opère une charnière dans son existence à attendre qu'on la réinvite au bal à la Vaubeysard.

- Je pense à tous ces personnages à caractère symbolique : le personnage de l'aveugle qui vient chanter une chanson d'amour dérisoire, le personnage de Justin, enfant à la main pure et qui se trouve être celui qui lui donne l'arsenic. C'est exactement ce que l'on va trouver chez Salammbô avec cette mort dont vous parliez lundi et dont on ne sait pas d'où elle vient. Tout simplement parce que le désir porte en lui la mort. ${ }^{23}$ 》

Enquanto é difundido este excerto de emissão radiofónica, vêem-se em grande plano sempre em tonalidades claro-escuro, as primeiras imagens da incorporação dos ingredientes, inicialmente a preto e branco: a farinha lançada para um recipiente com a inserção dos nomes dos atores, Gemma Arterton e Fabrice Luchini, incrustados em letras cursivas a branco. Ouve-se em voz off, o timbre inconfundível do popular ator francês Fabrice Luchini: ${ }^{24}$ «Joubert, c'est moi».

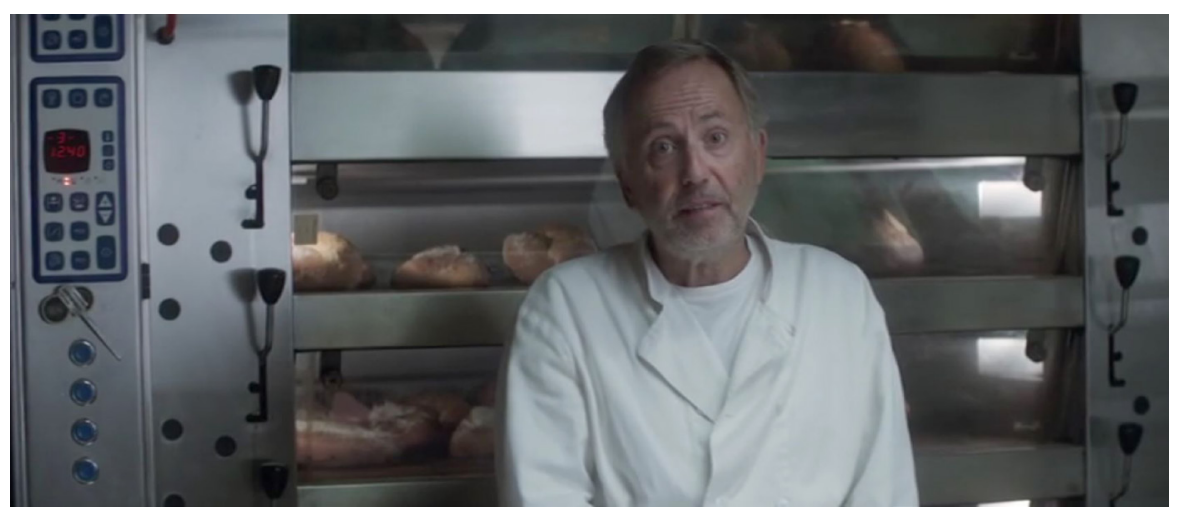

Ilustração 9: Fabrice Luchini no genérico do filme de Anne Fontaine 
0 fabrico do pão tem inclusive uma presença no filme que está ausente da novela gráfica que prefere simplesmente representar a padaria, provavelmente por ser graficamente mais interessante de desenhar. É o que acontece logo no primeiro desenho que representa o padeiro na sua loja rodeado dos diversos pães que comercializa. Imagem que se repete na parte final da novela como para significar a literariedade da BD, o fechamento da narração sobre ela mesma.

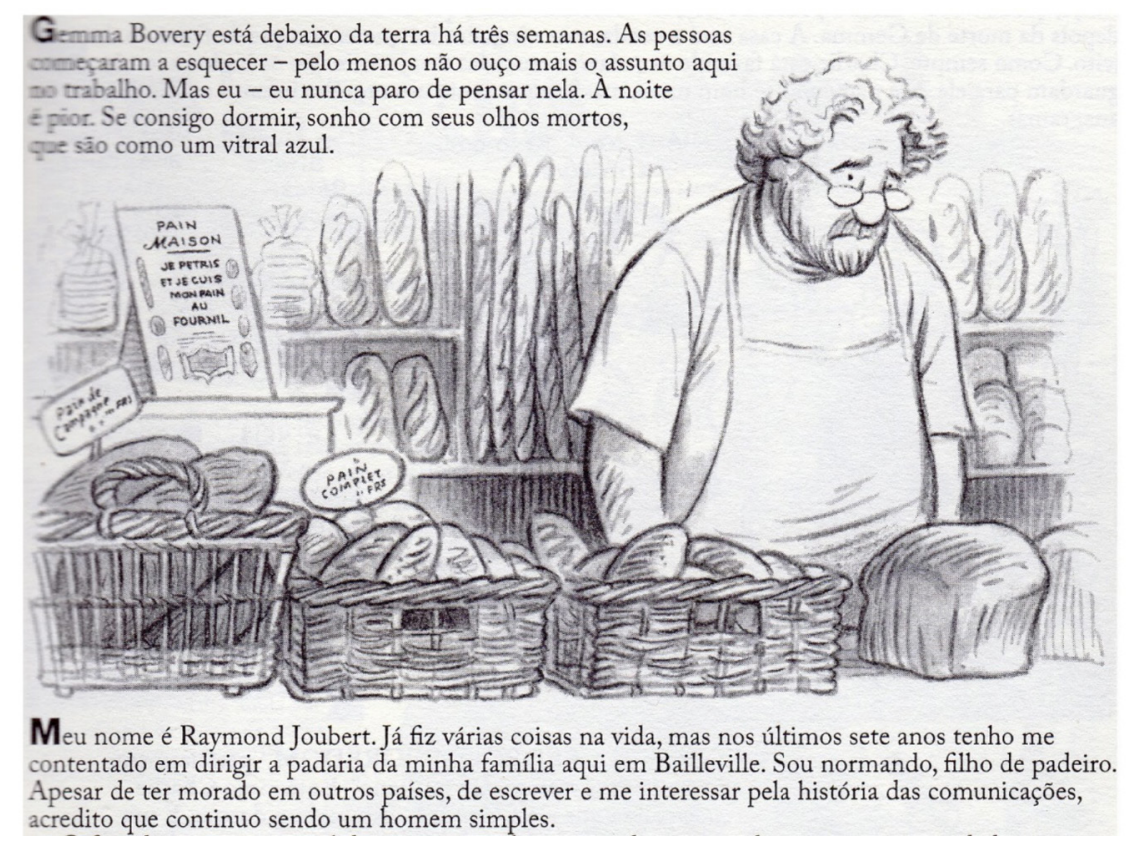

Ilustração 10: Simmonds, 2006, p.2

No filme uma outra sequência está ausente da obra de Simmonds quando Joubert ensina a Gemma a amassar o pão numa evidente alusão erótica e de afloramento do desejo provocado. A morte acidental de Gemma na parte final da novela e do filme ao se engasgar com um pedaço de pão amassado por Joubert ao mesmo tempo que é um fecho narrativo que surge nas duas obras funciona como reminiscência do romance francês. Emma Bovary em vários momentos declara que sufoca («J'étouffe») ou que padece de sufocos provocados pelo calor da primavera, pelo espartilho, pela angústia do endividamento, pelo cheiro de fruta que provoca lembranças e náuseas e, finalmente, depois de se envenenar com arsénico. 
Entre as similitudes e referências alusivas no hipertexto temos um curto diálogo entre duas personagens, uma que decalca o original criado por Flaubert e outra totalmente inventada pela desenhadora e que é a mãe do amante de Gemma.

Tate ? ... ah, non ! É minha mulher...Je suis Charles Bovery...

Bovary?

Ah ( ?!)

Florence de Bressigny

...Bonjour (Simmonds, 2006, p.88)

0 equívoco sobre o apelido permite introduzir uma subtil referência ao texto do escritor francês quando Charles Bovary, jovem estudante, é incapaz de pronunciar o nome de forma audível que é repetido deformado pelo professor. Acresce que o lugar onde Emma nasceu chama-se Tostes que fonologicamente tem semelhanças com «Tate». Na novela gráfica trata-se de uma inversão irónica na qual o marido adquire $o$ apelido da mulher. São semelhantes equívocos, afirmações de identidade e singularidade que percorrem as várias obras de que falámos neste artigo.

\section{Discussão}

As várias transposições fílmicas indiretas de Madame Bovary na impossibilidade de adaptar o inadaptável, como o reconhecem os vários autores e realizadores que se inspiraram na obra de Flaubert, conseguiram criar universos singulares que em vez de copiar um modelo dialogam com ele. Apresentámos e analisámos neste estudo não as várias cópias da história de uma mulher em desadequação com o meio, mas vários originais de tonalidade grave, apesar da ironia sempre presente, em Bessa-Luís e Oliveira, e de tonalidade ligeira próxima de uma comédia em Simmonds e Fontaine que inova ao propor na atualização questões e diferenças interculturais entre franceses e ingleses.

Verifica-se que apesar da diversidade das abordagens: filme baseado num romance que fala de outro romance e filme inspirado numa novela gráfica que transpõe para outra linguagem semiótica um romance, todas elas revelam a extraordinária plasticidade da obra seminal que permite todos os confrontos, todas as ousadias. 


\section{Referências bibliográficas}

Baecque, A. De \& Parsi, J. (1999). Conversas com Manoel de Oliveira. Porto, Campo das Letras.

Bessa-Luís, A. (1991). Vale Abraão. Lisboa: Guimarães Editores.

Flaubert, G. (1991). Correspondance III. Paris, Gallimard, Bibliothèque de la Pléiade.

Flaubert, G. (1999). Madame Bovary. Paris: Editions Gallimard, Folio Plus.

Flaubert, G. (2017). Madame Bovary. Lisboa: Clube do Autor.

Gaultier, J. de. (2006). Le Bovarysme. Suivi d'une étude de Per Buviq Le principe

bovaryque. Paris. Presses de l'Université Paris-Sorbonne.

Gravertt, P. (2019). So British! L'Art de Posy Simmonds. Paris: Éditions Denoël.

Simmonds, P. (2001). Gemma Bovery. London: Jonathan Cape.

Simmonds, P. (2006). Gemma Bovery. São Paulo: Conrad Editora.

Simmonds, P. (2014). Gemma Bovery. Paris. Denoël Graphic.

\section{Filmografia}

Fontaine, A. (Realizadora). (2014). Gemma Bovery. [DVD]. Paris: Gaumont. Oliveira, M. de. (Realizador). (2003). Vale Abraão. [DVD]. Lisboa: Madragoa Filmes.

\section{Notas}

[1] No romance é o próprio sedutor, Rodolphe Boulanger, que usa do artifício do nome para afastar Emma do marido: «esse nome, o nome que enche a minha alma e que deixei escapar, vejo que mo proíbe! Madame Bovary!... Toda a gente pode chamar-lhe assim !... Mas não é o seu nome; é o nome de outro!» (Flaubert, 2017, p. 198).

[2] Excerto traduzido por mim de uma carta de 1862 a Ernest Duplan : « jamais, moi vivant, on ne m'illustrera, parce que : la plus belle description littéraire est dévorée par le plus piètre dessin. [...] Une femme dessinée ressemble à une femme, voilà tout. L'idée est dès lors fermée, complète, et toutes les phrases sont inutiles, tandis qu'une femme écrite fait rêver à mille femmes. Donc, ceci étant une question d'esthétique, je refuse formellement toute espèce d'illustration.» (Flaubert, 1991, p.221-222). Numa conversa sobre Flaubert com Boyd Tonkin, crítico literário do periódico britânico The Independent, no Instituto Francês de Londres em 11/03/2011, a cartoonista Posy Simmonds fará maliciosamente uma leitura em inglês desta 
carta por ter infringido este desejo do escritor francês. Numa carta ao seu editor Georges Charpentier, em 02/02/1880, Flaubert dirá ainda que a ilustração é algo de "anti-literário". No estudo de Per Buvik «Le principe bovaryque» que acompanha a edição em 2006 de Le Bovarysme de Jules de Gaultier é sublinhada a evolução do conceito que passa da esfera da psicologia individual, primeiro à personagem de Flaubert, depois à uma faculdade humana e para, finalmente, atingir o princípio de mudança contínua do mundo.

[3] Segundo o Dicionário Houaiss da Língua Portuguesa: «faculdade que tem o ser humano de se conceber diferente do que é». 0 conceito evolui entre o momento em que Gaultier publica em 1892 Le Bovarysme. La psychologie dans l'oeuvre de Flaubert e em 1902 Le Bovarysme, Essai sur le pouvoir d'imaginer. A popularida do conceito terá também contribuído o ensaio de Georges Palante em 1912 La Philosophie du bovarysme. Jules de Gaultier, primeiro estudo sobre este conceito.

[4] No fim de uma conversa sobre Flaubert no Instituto Francês de Londres, Posy Simmonds responde a uma pergunta da sala que refere a célebre citação e interroga a desenhadora sobre a sua relação com Emma Bovary. Na resposta, a desenhadora afirma não ser Madame Bovary, mas antes se identifica com a personagem do padeiro: "Joubert, c'est moi". (cf.:https://www.youtube.com/watch?v=q-bskeVu-04).

[5] Referência ao Antigo Testamento, Génese, XVI, 5.

[6] Na novela gráfica de Posy Simmonds não existe nenhum episódio equivalente ao baile. Porém, no filme Gemma Bovery, provavelmente no ensejo de introduzir mais uma referência interartística, durante um passeio no campo de Martin (e não Raymond como na novela) Joubert na companhia de Gemma, este La Boissière entre as árvores onde dez anos, do tempo do velho Bressigny, davam-se grandes festas. Anne Fontaine antecipa assim na diegese do filme os encontros amorosos de Gemma com Hervé, filho da senhora de Bressigny.

[7] Como relata em entrevistas e conversas, a ideia de atualizar Madame Bovary aconteceu durante umas férias em Itália quando na esplanada de um café viu uma "bela italiana" com o namorado que "tratava como se fosse um cão", rodeada de sacos de marcas de luxo, e que, suspirando de forma ruidosa, transmitia um sentimento de tédio. Para Simmonds esta italiana representou de imediato a eternidade do "bovarismo". No regresso disse ao editor que pretendia fazer uma Bovary dos nossos dias e que esta seria inglesa. Depois de uma releitura da obra fechou o livro numa gaveta para não ser, como ela conta, "influenciada».

[8] Desenha locais da Normandia próximos da Yonville imaginada por Flaubert, estabelecendo inclusive a planta das casas.

[9] Posy Simmonds, numa apresentação onde esteve também a realizadora Anne Fontaine, na Bibliothèque Publique d'Information (BPI) do Centro Pompidou em Paris, regressa a esta similitude entre o trabalho de desenhador e o de cineasta, acrescentando que foi simultaneamente argumentista, produtor, diretor da fotografia ao criar Gemma Bovery. Esta analogia entre novela gráfica e filme estende-se ao conceito de montagem onde retira desenhos e páginas inteiras na parte final do trabalho. (cf.: http://archives-sonores.bpi.fr/index.php?urlaction=doc\&id doc=4070\# ) 
[10] Posy Simmonds evoca também esta analogia num artigo do Le Monde de 30/01/2009.

[11] A novela gráfica Gemma Bovery inaugura uma nova coleção dirigida por Fromental na editora parisiense Denöel, mais conhecida por publicar literatura e ensaios, como este refere na conversa da BPI.

[12] Ao lhe ser perguntado por Jean-Claude Loiseau, crítico de BD, na BPI a que se deve o título Gemma Bovary, Posy Simmonds responde simplesmente que para um inglês as iniciais do nome são G.B., Great Britain. A resposta até poderá ser uma ironia, mas, de qualquer forma, não se pode encontrar melhor exemplo de naturalização. Na capa da edição inglesa estão representados em primeiro plano a heroína Gemma Bovery e no segundo plano um Volkswagen Bus, também conhecido como T2, vulgo "pão de forma" em Portugal, branco e cor-de-laranja visto de trás com a placa de país G.B. bem visível. Iniciais que também reencontramos, mas de forma menos discernível em desenhos no interior da novela. Indício icónico que desaparece da capa da edição brasileira da Conrad Editora.

[13] Na conversa na BPI Anne Fontaine prefere utilizar o verbo "inspirar-se" em vez de "prolongar" a novela gráfica.

[14] Apesar da importância dada ao vestuário e acessórios na novela gráfica, a realizadora detém-se ainda mais nestes pormenores, destacando-se uma sequência quase no início do filme, ausente da novela gráfica, onde Joubert e a mulher, depois do conserto de um fusível, se encontram em casa dos Bovery a beber à lareira. Vê-se o olhar de Joubert que desce até ao botim. É de realçar que este tipo de calçado, a "bottine" é constantemente referido no romance de Flaubert.

[15] Expressões utilizadas pela cineasta na BPI. No fim da sessão revela que conheceu Fabrice Luchini quando este tinha 23 anos e só falava em Madame Bovary. Mais tarde chamou inclusive à filha Emma.

[16] Não será simples mero acaso que o apelido do padeiro Joubert rime com o nome de Flaubert.

[17] No romance de Flaubert, Hervé de Bressigny é um misto de Léon Dupuis, jovem amanuense num gabinete de notário a estudar Direito e de Rodolphe Boulanger, proprietário do castelo de la Huchette.

[18] Na versão brasileira o termo encontrado é menos feliz: «Foi então que notei Hervé de Bressigny, também parado ali feito um manequim. Algo muito estranho aconteceu. Um segundo depois que olhei para ele, foi como se, como um diretor de cinema, eu tivesse gritado "AÇÃO!" Ele ganhou vida. Falou com Gemma! Foi como se eu tivesse determinado o que ele fosse fazer, como se eu tivesse guiado Gemma a... (Simmonds, 2006, p. 56).

[19] Daí a inserção de vocábulos em francês nos balões das personagens francesas e no texto da própria narração para dar uma maior autenticidade e instituir uma cumplicidade com os leitores cultos do The Guardian, alguns deles seguramente francófilos. Expressões em francês são igualmente utilizadas quando ingleses se dirigem a franceses. Esta mistura linguística é retomada no filme e ganha maior expressividade pelo facto do elenco ser composto por atores franceses e ingleses como Gemma Arterton representando a heroína.

[20] Excerto da emissão «Les Nouveaux chemins de la connaissance», programa da rádio pública France Culture, de 11/05/2011, produzida por Raphaël Enthoven e com as intervenções de Michel Schneider, escritor e psicanalista e Pa- 
trick Dandrey, professor de literatura francesa da Universidade de Paris-Sorbonne. (cf.:https://www.franceculture.fr/emissions/les-nouveaux-chemins-de-la-connaissance/ flaubert-35-madame-bovary)

[21] « On les regardait. Ils passaient et revenaient, elle immobile du corps et le menton baissé, et lui toujours dans sa même pose, la taille cambrée, le coude arrondi, la bouche en avant. Elle savait valser, celle-là ! Ils continuèrent longtemps et fatiguèrent tous les autres. » Parte I, capítulo VIII, Madame Bovary, Folio plus, nº40, 1998, p. 82

[22] Não menos anacrónico é a utilização de um célebre canto da época da União Soviética, Plaine, Ma Plaine, interpretado pelos Coros do Exército Vermelho, composto em 1934 por Lev Knipper com letra de Victor Goussev, que se ouve durante a ficha técnica do genérico final, forma de rematar o quiproquó final quando Joubert acredita que o apelido dos novos vizinhos é Kalénine numa alusão transparente ao romance de Tolstoi.

[23] Tradução minha: «Estamos então na Vaubeysard, no famoso baile da Vaubeysard, episódio cardeal da existência de Madame Bovary, ao seja talvez o momento onde os seus sonhos, pelo menos assim o crê, se encarnam. Patrick Dandrey - Certamente

- E que, desta forma, constitui uma charneira na sua existência ao esperar que seja novamente convidada para 0 baile da Vaubeysard. - Penso em todas as personagens com caráter simbólico: a personagem do cego que vem cantar uma canção de amor derisória, a personagem de Justin, criança com a mão pura e que é quem lhe dá o arsénico. É exatamente o que iremos encontrar em Salammbô com esta morte da qual falava na segunda-feira e que não se sabe de onde vem. Simplesmente por que o desejo traz em si a morte.»

[24] Ator, nascido em 1951, que se estreou no cinema no filme de Éric Rohmer, Le Genou de Claire, em 1970. Depois da sua interpretação em 1978 de Perceval le Gallois, adaptado do romance medieval homónimo de Chrétien de Troyes pelo mesmo cineasta, é rotulado de interprete de filmes de autor antes de participar, sobretudo a partir da década de 90, em muitas comédias subtis.

\section{(9) $(1)$ ( $)$}

Esta obra está bajo una licencia de Creative Commons Reconocimiento-NoComercial 4.0 Internacional. 